\title{
Expert trio take on Africa's health care problems - one step at a time
}

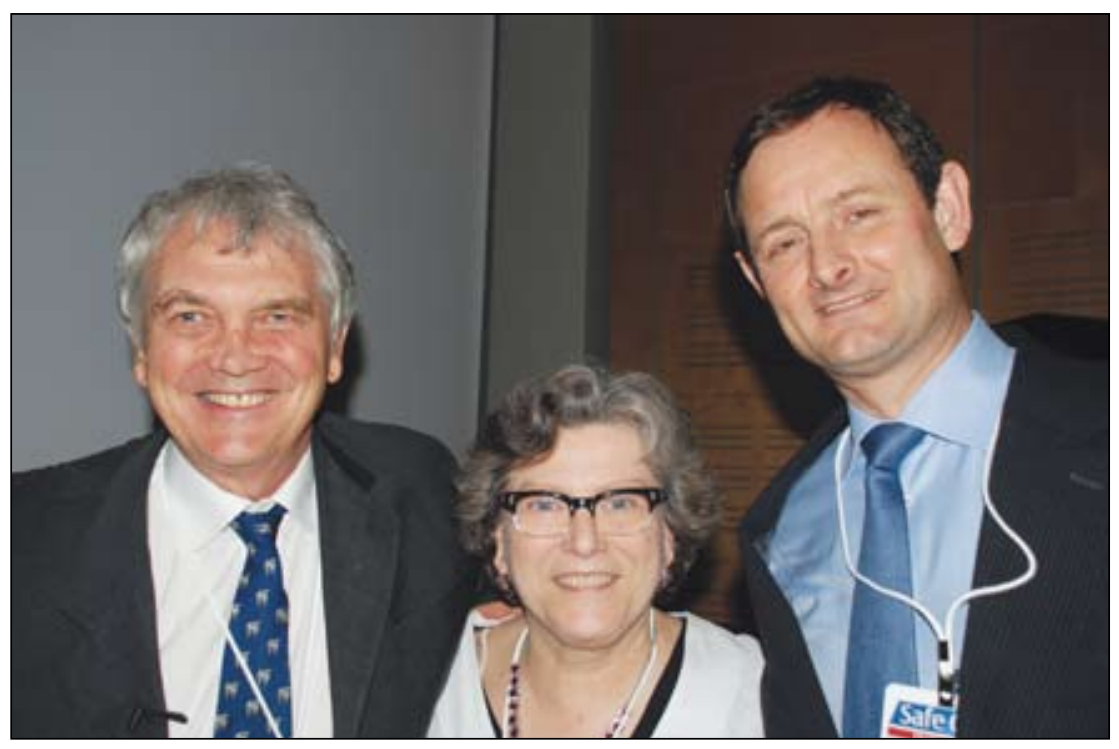

Professor Stuart Whittaker, CEO of the Council for Health Service Accreditation of Southern Africa (COHSASA), Paula Wilson, President and CEO of the Joint Commission International (JCI), and Joint Commission Resources (JCR), and Mr Michiel C de Wilde, MD of the Holland-based PharmAccess Foundation after signing a Memorandum of Understanding on their ambitious African quality healthcare improvement venture.

Africa's debilitating quarter share of the world's disease burden, with just $3 \%$ of the globe's health workers and $1 \%$ of its finances, is to be tackled through a uniqueinternational partnership involving a top South African NGO. Aimed at improving quality, access and affordability and beginning with subSaharan Africa, the partnership will upgrade health care facilities by offering a quality improvement framework and incentivised performance-based loan mechanisms. At the same time the majority low-income patients will be offered pragmatic subsidised voluntary private health insurance via a prepayment scheme.

The local Council for Health Service Accreditation of Southern Africa (COHSASA), its global equivalent Joint Commission International (JCI) - a World Health Organization (WHO)-designated Collaborating Centre for Patient Safety Solutions and PharmAccess, an innovative Dutch health capacity-building and economic empowerment body, held a founding conference in Cape Town last month.

They aim to bring their considerable skills, resources and experience to bear by identifying problems in every department at selected health care facilities and incrementally providing support and incentivised funding to upgrade them.
Picture: Chris Bateman

The latest technology will be brought to bear in assessing and monitoring facilities with advanced computer information systems and hand-held devices enabling adverse event reporting, report generation and at-a-glance access to any data for management.

\section{The latest technology will be brought to bear in assessing and monitoring facilities with advanced computer information systems and hand-held devices enabling adverse event reporting, report generation and at-a- glance access to any data for management.}

The first chairperson of the initiative, Professor Stuart Whittaker, who is also COHSASA's founder and CEO, stressed that 'this is not a quick-fix but rather an incremental process towards excellence. Properly applied, it will mean that health workers will be able to meet professional and internationally accredited standards of safety and quality and therefore be in a position to provide the same to their patients'.

The United States-based JCI will make available standards and evaluation methods designed to provide quantifiable benchmarks for patient quality care as well as a set of sophisticated staff e-training modules. COHSASA will offer its web-based quality information system that guides the process towards quality improvement and accreditation. It does this by measuring compliance levels against set standards and identifying deficiencies in a prioritised order. PharmAccess's main role will be to use its (Dutch government, WHO-funded and potentially USAIDS-funded) Health Insurance Fund (R250 million at the time of writing, but probably up to R390 million if a USAID application succeeds) and Medical Credit Fund (currently at R20 million and climbing) to respectively initiate voluntary private health insurance and provide complementary financial support and technical help to medical providers through performance-based loan mechanisms.

\section{Facility successes compounded}

Once facilities show improvement (with graded certification awards that enable patients to assess their quality of care and thus enhance their reputation), they can also negotiate being part of insurance programmes and attract foreign loans or investment.

\section{Health care pre-payment a foreign concept among the poor}

Michiel de Wilde, CEO of PharmAccess, told Izindaba that for many indigent or low- 
income Africans, the entire concept of prepaying to insure oneself for unknown risk was a foreign concept. 'We play what we call a Treasury Pot game with them, be they dairy farmers or market women. Initially they each get five pieces of candy or marbles and are asked to draw a card graphically describing some kind of health problem. Each card or condition has a candy or marbles numerical value or currency. Let's say a cardiovascular problem costs eight marbles but you only have five, so you sit in hospital until you get more marbles. It turns out that most of them get into trouble because they don't have the means to solve the medical problem.'

The next phase of the game involves participants pooling their currency and almost everyone being helped - but with no currency left to buy food. The third and final phase sees each participant put two of their marbles/candy into the pot and the Health Insurance fund add three (per person) everyone then gets health care without going hungry.

De Wilde said that by avoiding 'catastrophic risk' in this way and over time increasing subsidised co-payments, a community or country's economy and health improved markedly. Operational research in Nigeria was showing that pregnant women on the scheme were already visiting clinics more often. He said PharmAccess's corporate programme in Namibia for example (Heineken) was expanding into rural areas using mobile clinics and building experience for replication in the SafeCare Initiative.

De Wilde said he first met up with Whittaker at a quality care conference some seven years ago and 'over time we developed the idea of working together - it's a natural fit; we do performance-based financing and they do care quality improvement'. The initiative will also create an open-source platform to encourage health care workers in resourcelimited countries to share knowledge and experience and store the wealth of data generated by the projects.

\section{The initiative will also create an open-source platform to encourage health care workers in resource-limited countries to share knowledge and experience and store the wealth of data generated by the projects.}

\section{Creating a data gold mine}

Erwin Schella, Professor of Public Leadership at the University of Stellenbosch and a COHSASA board member, said the idea behind what will be called the SafeCare Institute was to become the leading international think-tank for safe health care in resource-restricted settings. He will collate data and lead the academic institute, initiating research based on the vast amount of data generated.

'The potential for innovation is limitless. We want to create a cutting-edge forum for and within organisations and provide a platform for knowledge management. We cannot afford to lose the richness of these data. I want to move away from policy rules and power-dominated bureaucracy and create something where knowledge

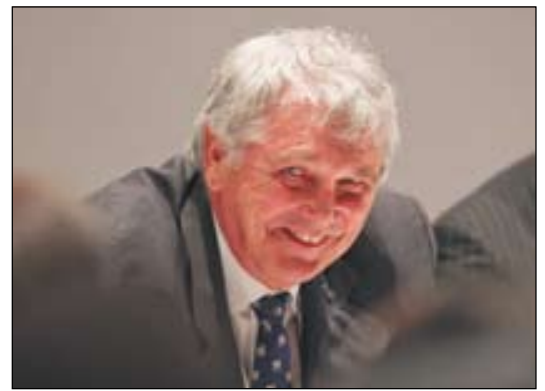

Professor Stuart Whittaker, CEO of the Council for Health Service Accreditation of Southern Africa.

networking and relationships will be dominant so that we can come up with a lot of possible research projects to improve quality in health. We want co-operation, rather than control, to be strong on vision and weak on boundaries,' he enthused.

${ }^{*}$ COHSASA has worked in over 530 facilities in both the public and private sector in South Africa, Namibia, Botswana, Swaziland, Lesotho, Rwanda, Nigeria and Zambia over the past 16 years. The council operates in hospitals, clinics, hospices and sub-acute facilities. PharmAccess first gained profile with its HIV/AIDS workplace program for Heineken in 2001 and today works in over 30 countries with offices in Amsterdam (co-ordinating centre), Namibia, Nigeria, Kenya and Tanzania. JCI, established in 1994, consults, educates and internationally accredits facilities in more than 80 countries.

\section{Chris Bateman}

